УДК 37(091)(477):34

DOI: $\underline{10.35619 / \text { iiu.v1i13.352 }}$

Петрушко Юлія

здобувачка ступеня $\mathrm{PhD}$

кафедри теорії і методики виховання

Рівненського державного гуманітарного університету,

м. Рівне, Україна

ORCID: 0000-0001-7752-5938

e-mail:mosievuch007@ukr.net

\title{
НОРМАТИВНО-ПРАВОВЕ ЗАБЕЗПЕЧЕННЯ ВІТЧИЗНЯНОЇ ДОМАШНЬОЇ ОСВІТИ У ДРУГІЙ ПОЛОВИНІ ХІХ СТ. (НА ОСНОВІ АНАЛІЗУ «ПОЛОЖЕННЯ ПРО ДОМАШНІХ НАСТАВНИКІВ І ВЧИТЕЛІВ» 1834 р.)
}

Анотація. У статті аналізується система державного регулювання діяльності домашніх наставників і вчителів та розвиток домашньої освіти другої половини XIX ст. Особлива увага приділена розгляду нормативноправової бази, зокрема «Положення про домашніх наставників і вчителів» 1834 р. На основі досліджених і проаналізованих архівних документів та історико-педагогічних праць обгрунтовано, що створена правова база щодо здійснення навчально-виховного процесу в домашніх умовах офіційно визнала і закріпила позиції домашньої форми освіти.

Доведено, що у другій половині XIX ст. на законодавчому рівні були затверджені необхідні умови допуску осіб до навчання і виховання дітей в приватних будинках: наявність спеціальної освіти i моральна «благонадійність» особистості, що включала політичні переконання, лояльне ставлення до царату та устрою Російської імперії. 3'ясовано, що домашніми наставниками та вчителями могли бути також іноземці, проте нормативна політика імперської влади щодо їхньої педагогічної діяльності мала свої особливості і була спрямована на зменшення впливу іноземних педагогів у сфері домашньої освіти. Визначено характеристики особистісних та професійних якостей домашніх педагогів; зазначено, що на офіційному рівні були закріплені пільги та привілеї, які надавалися домашнім педагогам.

Ключові слова: домашня освіта, домашній наставник, домашній вчитель, нормативно-правове забезпечення, «Положення про домашніх наставників і вчителів».

Постановка проблеми. Домашня освіта як педагогічне явище відоме у світі і в Україні з давнього часу, воно пройшло кілька етапів свого становлення і розвитку та залишається досить поширеним й у сучасних умовах. Аналіз історико-педагогічної літератури свідчить, що у XIX ст. відбулося впровадження масового шкільного навчання та як альтернативи 


\section{Інноватика у вихованні. Випуск 13.Том 1. 2021.}

(для більш заможних людей) домашньої освіти. XIX ст. - період розквіту системи домашнього навчання, особливо у Російській імперії (до складу якої входила велика частина українських земель, в тому числі й Волинська губернія). У XIX ст. були прийняті закони, якими встановлювався майже абсолютний контроль за системою домашнього виховання - це був період чіткої законодавчої регламентації процесу домашнього навчання та іiі повного включення у систему державної освіти.

Пандемія короновірусної інфекції спричинила низку кардинальних змін в українській освіті. Закриття шкіл і екстрений перехід на дистанційне навчання зумовили низку проблем та показали відсутність або слабку підготовку педагогів до роботи в нових умовах. 3 огляду на це особливої важливості набуває вивчення історичного досвіду у сфері домашньої освіти, зокрема, державна політика щодо домашнього виховання i навчання задля можливості використовувати найбільш ефективні практики в сучасних умовах.

Аналіз останніх досліджень 3 проблеми. На основі опрацьованих джерел і літератури виявлено зацікавленість різними аспектами домашньої освіти. У працях Є. Сарапулової (2003) та М. Денисенко (2010) висвітлено вимоги до організації та особливості діяльності гувернерів в Україні, домашня освіта розглядається як складова приватної. У працях Ю. Агапова (2011) представлено грунтовний аналіз домашньої форми освіти як складової приватної освіти на Волині. У дослідженнях О. Драч (2012) та Л. Прокопенко (2019) особлива увага приділена розгляду процесу формування нормативно-правової бази приватної освіти. Однак, попри значну кількість праць, які розкривають різноманітні аспекти домашньої освіти, питання щодо вимог до діяльності домашніх наставників та вчителів на основі нормативних актів зазначеного періоду потребує детального вивчення.

Мета статті - здійснити аналіз законодавчої політики у сфері діяльності домашніх педагогів на основі «Положення про домашніх наставників і вчителів» 1834 року та з'ясувати його вплив на розвиток домашньої освіти у Волинській губернії в другій половині XIX - на початку XX ст.

Виклад основного матеріалу дослідження. Домашня форма освіти як традиційний спосіб набуття знань, що успішно проіснувала на території Російської імперії до початку XX століття, була юридично закріплена Законом 1737 р., згідно 3 яким особам дворянського походження надавалося право «навчати своїх синів вдома 3 перевіркою результатів цього навчання державою» (Рождественский, 1910). 3 цією метою, за законом, особам, що здобували освіту приватно, встановлювалися «огляди» для перевірки знань з різних предметів (залежно від віку). Проте у документах цей вид навчання особливо не виділяли. До першої половини XIX ст. домашня освіта регламентувалася тими нормативно-правовими документами, яких дотримувалися як державні, так і приватні навчальні 


\section{Інноватика у вихованні. Випуск 13.Том 1. 2021.}

заклади. Офіційне законодавче поле відносно цього виду освіти було прийняте в 1834 р. (Агапов, 2011, с. 102).

Важливі узагальнення щодо вимог організації діяльності домашніх наставників і вчителів другої половини XIX ст. висвітлено у «Положенні про домашніх наставників та вчителів», опубліковано в «Журналі Міністерства народної освіти» 1 липня 1834 р. Зокрема, документом офіційно встановлювалися звання домашніх наставників, вчителів і вчительок, зазначався їхній спектр обов'язків, освітній ценз, матеріальне забезпечення і привілеї. Аналіз змісту цього положення свідчить про серйозне ставлення суспільства, педагогічної громадськості та педагогів до домашньої освіти та організації педагогічної підготовки домашніх наставників.

«Положення про домашніх наставників та вчителів» складалося із семи розділів, які вміщували 69 параграфів. Зокрема, Розділ I. Загальні положення; Розділ II. Про різноманітні звання, які надаються особам, які займаються вихованням дітей у приватних будинках; Розділ III. Про іспити; Розділ IV. Про вигоди, які надаються тим російським підданим, що отримують право виховання дітей у приватних будинках; Розділ V. Про домашніх вчительок; Розділ VI. Про капітал опіки; Розділ VII. Про відповідальність за порушення цього «Положення» (Положение о домашних наставниках и учителях и дополнительные к нему постановления, 1834).

Аналіз змісту документа засвідчує, що основним у першому розділі було визначення звань, які могли отримувати домашні педагоги, а саме: домашнього наставника i наставниці, вчителя та вчительки. Домашні наставники (наставниці) було ширшою спеціалізацією, оскільки вони виконували навчальні та виховні функції. Домашні вчителі і вчительки згідно з існуючим на той час законодавством обмежувалися здійсненням лише навчального процесу. Необхідно зазначити, що у документі звання «домашній наставник» означало першу вищу ступінь домашнього педагога, а до другого ступеня відносилися домашні вчителі, які не мали вищої освіти (Балабуст, 2013, с. 22). Також у «Положенні» аналізувалося звання наглядача та наглядачки. Їхні обов'язки обмежувалися лише фізичним вихованням дітей, тому від них не вимагалося ніяких іспитів i свідоцтв.

Важливим у розділі $є$ визначення загальних вимог до домашніх педагогів. Займатися вихованням дітей могли люди вільних станів, християнського віросповідання, добропорядні в аспекті їхньої моральності (Днепров, 2017, с. 338). Тож на законодавчому рівні були закріплені не лише професійні, але й особистісні вимоги до домашніх педагогів.

Одним iз найважливіших аспектів «Положення про домашніх наставників і вчителів» є виокремлення вимог до претендентів на ці звання, в основу яких покладено освітній рівень домашніх педагогів. У параграфі 9 було зазначено, що звання домашнього наставника може бути присвоєно тим особам, які закінчили повний курс навчання у вищих навчальних 


\section{Інноватика у вихованні. Випуск 13.Том 1. 2021.}

закладах, склали успішно іспити та отримали атестат дійсного студента або диплом ученого ступеня як російських університетів, так i духовних академій (Сборник постановлений по Министерству народного просвещения, 1875). Домашніми наставниками могли бути також військові у відставці та державні чиновники, проте стосовно них діяли певні доповнення: ці особи до пакету документів мали надати атестати, видані їм при відставці. Уряд, контролюючи якість домашньої освіти, не допускав до роботи з дітьми осіб, які були звільнені з роботи через недобропорядну поведінку, засуджені або притягнуті до суду (Денисенко, 2010, с. 25). Право отримати звання домашнього вчителя мали також ті, хто не мав вищої освіти, проте успішно склав іспити 3 тих предметів, які мав викладати, а також вчителі гімназій у відставці зі стажем роботи не менше трьох років (Положение о домашних наставниках и учителях и дополнительные к нему постановления, 1834).

Унаслідок аналізу Положення, а саме розділу III, можна зробити висновок, що однією із найважливіших вимог до кандидата на звання домашнього вчителя була його науково-педагогічна обізнаність, яку перевіряли на практиці завдяки іспитам. Вони проводилися в університетах, а в тих губерніях, де вищих навчальних закладів не було, у гімназіях.

Іспити поділялися на три групи: іспити із загальних предметів (усний іспит із Закону Божого, письмовий і усний іспит з російської мови); іспити iз основних предметів (письмові та усні іспити 3 російської мови, математики, історії, географії, новітні європейські та давні класичні мови); іспити 3 допоміжних предметів (два питання 3 кожного предмета i проведення пробного уроку) (Сарапулова, 2003, с. 47). Особи, які мали незадовільні знання із загальних предметів, до наступних іспитів не допускалися. При отриманні незадовільної оцінки можна було через півроку повторно скласти іспит (Положение о домашних наставниках и учителях и дополнительные к нему постановления, 1834).

Переконавшись в моральних якостях, здібностях і знаннях вибраного предмета, попечитель навчального округу вручав кандидату на звання домашнього вчителя свідоцтво про присвоєння йому цього звання, а списки і повна інформація про таких вчителів направлялась в Міністерство народної освіти для подальшого контролю за їхньою діяльністю.

У другій половині XIX ст. домашніми вчителями у Російській імперії могли бути іноземці. Проте, як свідчить аналіз зазначеного положення, до них були особливі умови (параграф 17) (Положение о домашних наставниках и учителях и дополнительные к нему постановления, 1834). Окрім успішної здачі іспитів на загальних підставах, вони мали надати документи про хрещення і схвальний відгук від російської місії за кордоном, звідки вони прибули. Для іноземних підданих, які тривалий час мешкали в Російській імперії, такі посвідчення не були потрібні. Водночас вони були зобов'язані подати довідку про поведінку та моральні якості від місцевої адміністрації і благонадійних осіб. Проте навіть після отримання 


\section{Інноватика у вихованні. Випуск 13.Том 1. 2021.}

свідоцтва іноземні піддані не удостоювалися пільг, якими були удостоєні домашні наставники i вчителі. Положення переклали на французьку i німецьку мови з метою поширення серед російських місій за кордоном для ознайомлення іноземців з умовами допущення до педагогічної діяльності на території імперії (Драч, 2012, с. 17).

Безпосереднім результатом вжитих урядом заходів стало помітне зменшення чисельності приїжджаючих у Росію потенційних вихователівіноземців. Міністр народної освіти С. Уваров позитивно оцінював таку тенденцію, вважаючи, що «розпорядження щодо нагляду за домашнім вихованням належать до заходів, наслідки яких визрівають повільно, проте обіцяють безсумнівний успіх, оскільки грунтуються на засадах здорового глузду і державної передбачливості» (Общий отчет, представленный его императорскому величеству по Министерству народного просвещения за 1836 год, с. 94). При цьому він особисто ознайомлювався з інформацією, що надходила до Міністерства від попечителів щодо виданих свідоцтв на право навчання в приватних будинках, звертаючи увагу на найменші неточності при фіксації відомостей (Драч, 2012, с. 18). Незважаючи на коливання урядової політики в цій сфері, практика домашнього виховання з використанням іноземних педагогів проіснувала в Російській імперії до 1917 року.

Достатньо вагому частину документу складають положення щодо пільг і переваг домашніх педагогів, яким відведено цілий розділ (параграфи 28-50) (Положение о домашних наставниках и учителях и дополнительные к нему постановления, 1834). Домашні наставники i вчителі зараховувались на дійсну державну службу через Міністерство народної освіти. Протягом всієї служби вони мали право носити службовий мундир з губернськими гербами на гудзиках. За десять років бездоганної служби такі особи могли бути нагороджені золотою або срібною медаллю і орденською стрічкою Св. Олександра Невського. 3 часу зарахування на ці посади домашнє вчительство отримувало певний чин, після шести років наставники отримували підвищення, а вчителі - після восьми років відмінної роботи. Водночас, вихідці 3 родових дворян нагороджувались орденом Св. Станіслава четвертого ступеня через 15 років, з простих дворян - через 20 років, з інших станів - через 25 років. Наставники відповідно нагороджувались орденом Св. Анни третього ступеня. Обидві категорії через 35 років бездоганної роботи могли нагороджуватись орденом Св. Володимира четвертого ступеня. Наставник, який протягом 25 років сумлінно виконував свої обов'язки, а також підготував до вступу в університет не менше трьох учнів, здобував почесне звання «Заслужений наставник» (Гоголин, 1874, с. 16-18).

Такі особи, які дожили до похилого віку або важко захворіли і не мали достатніх засобів для нормального проживання, одержували пожиттєву фінансову допомогу за рахунок спеціальних коштів («капіталу опіки») департаменту народної освіти. Цей капітал складався зі зборів, які брались на підставі положення 20 лютого 1823 р. зі свідоцтв на право навчання у 


\section{Інноватика у вихованні. Випуск 13.Том 1. 2021.}

приватних будинках, 3 атестатів на звання наставників i вчителів (Прокопенко, 2019, с. 120).

Політика Російської імперії щодо домашньої освіти грунтувалася і на більш жорсткому контролі дотримання законодавства, тому поряд із пільгами відповідальність за порушення положення та у проаналізованому документі було юридично закріплено (Розділ VII). Зокрема, в окремих статтях зазначалося, що особи, які працювали домашніми вчителями i наставниками без свідоцтв, мали сплатити штраф 250 рублів асигнаціями. Аналогічний штраф сплачували і батьки, родичі чи опікуни, в яких працював такий педагог. Якщо аналогічний випадок повторювався, то іноземців виселяли за кордон, а місцеві педагоги відповідали в суді (Положение о домашних наставниках и учителях и дополнительные к нему постановления, 1834).

У 1863 р. і 1868 р. царський уряд вніс низку доповнень і змін до «Положення про домашніх наставників і вчителів» (1834р.) щодо конкретизації статусу цих осіб. Було підтверджено, що звання «домашній наставник» присвоюється тільки при наявності вищої освіти. Педагоги гімназії й інших аналогічних навчальних закладів, а також вчителям повітових училищ, які вийшли у відставку i не мали вищої освіти, дозволялось працювати домашніми вчителями в приватних оселях після відповідних випробувань. Водночас зменшувалась тривалість роботи для надання вищих чинів: домашнім наставникам до трьох, вчителям - до шести. Дещо змінювались терміни служби щодо нагороджень та деяких пільг (Балабуст, 2013, с. 22).

Висновки і перспективи подальших розвідок. Отже, прийняття «Положення про домашніх наставників і вчителів» у 1834 році. розпочало новий етап розвитку домашньої освіти в Російській імперії, який тривав до 1917 року. Його характерними особливостями були: чітка законодавча регламентація роботи домашніх педагогів (підготовка кадрів, обсяг роботи, оклад, пенсійне забезпечення і т.д.), визначення урядом важливості домашньої освіти та іiї використання.

На основі аналізу змісту «Положення» доведено, що у другій половині XIX ст. відбувся процес визнання домашнього навчання як повноправного компонента освітньої сфери, а законодавчо-нормативне регулювання цього явища протягом зазначеного періоду у контексті урядового курсу щодо розширення контролю за навчанням і вихованням у Російській імперії сприяло подальшому визнанню правових і соціальних гарантій держави для домашніх наставників і вчителів.

\section{СПИСОК ВИКОРИСТАНИХ ДЖЕРЕЛ}

Рождественский, С. (1910). Две записки М. М. Сперанского. Материалы для истории учебных реформ в России в XVIII - XIX вв. СанктПетербург. 397 с. 


\section{Інноватика у вихованні. Випуск 13.Том 1. 2021.}

Агапов, Ю. (2011). Індивідуальні форми приватної освіти на Волині (друга половина XII - початок XX століття). Вісник Житомирського державного університету, Випуск 57. Педагогічні науки. СС. 101-106.

Положение о домашних наставниках и учителях и дополнительные $\kappa$ нему постановления. ЦДА України. Ф. 707. Оп. 1. Спр. 753. Рік $1834-1838$.

Балабуст, Н. (2013). Місце і роль домашнього навчання в освітній сфері Подільської губернії (XIX - початок XX ст.). Педагогічна освіта: теорія і практика. Вип. 14. СС. 18-27.

Днепров, Э. (2017). Российское законодательство об образовании XIX - начала ХХ века. Москва: Изд. дом Высшей школы экономики. 832 с.

Положение о домашних наставниках и учителях. (1875). Сборник постановлений по Министерству народного просвещения. СанктПетербург. T.II. CC. 784-798.

Денисенко, М. (2010). Вимоги до організації діяльності гувернерів в Україні у першій половині XIX ст. Педагогічні науки: теорія, історія, інновачійні технологї. № 7. СС. 23-29.

Сарапулова, С. (2003). Психолого-педагогічні основи навчальновиховної діяльності гувернера. К.: МАУП. 264 с.

Драч, О. (2012). Політика державної влади Російської імперії щодо педагогічної діяльності іноземців у XIX ст. Вісник Черкаського університету. Серія: Історичні науки. Вип. № 29 (242). СС. 15-20.

Общий отчет, представленный его императорскому величеству по Министерству народного просвещения за 1836 год. (1837). СПб.

Гоголин, А. (1874). Сборник узаконений и правительственных распоряжений, касающихся домашних наставников, учителей, учительнии и наставнии. М. 38 с.

Прокопенко, Л. (2019). Державне регулювання розвитку приватної освіти на Катеринославщині у першій половині XIX ст. Аспекти публічного управління. Т. 7. № 1-2 с. 116-122.

\section{REFERENCES}

Rozhdestvenskiy, S. (1910). Dve zapiski M. M. Speranskogo. Materialy dlya istorii uchebnykh reform v Rossii v XVIII - XIX vv. [The two notes by $M$. M. Speranskyy]. SPb. 397 s. [in Russian].

Ahapov, Yu. (2011). Indyvidualni formy pryvatnoi osvity na Volyni (druha polovyna XIX - pochatok XX stolittia). [Individual forms of the private education in Volyn (second half of the $12^{\text {th }}$ - beginning of the $20^{\text {th }}$ century)]. Visnyk Zhytomyrskoho derzhavnoho universytetu, Vypusk 57. Pedahohichni nauky. SS. 101 - 106. [in Ukrainian].

Polozheniye o domashnikh nastavnikakh $i$ uchitelyakh $i$ dopolnitelnyye $k$ nemu postanovleniya [Regulations on the home tutors and teachers and Additional regulations]. TsDA Ukraïni. F. 707. Op. 1. Spr. 753. Rik 1834 1838. [in Russian].

Balabust, N. (2013). Mistse i rol domashnoho navchannia v osvitnii sferi Podilskoi hubernii (XIX - pochatok XX st.). [Status and role of the Ukrainian 


\section{Інноватика у вихованні. Випуск 13.Том 1. 2021.}

education of the Podillia province (XIX - beginning of the $20^{\text {th }}$ century)]. Pedahohichna osvita: teoriia i praktyka. Vyp. 14. SS. 18 - 27. [in Ukrainian].

Dneprov, E. (2017). Rossiyskoye zakonodatelstvo ob obrazovanii XIX nachala XX veka [Russian educational legislation of the $19^{\text {th }}$ - beginning of the $20^{\text {th }}$ century]. M.: Izd. dom Vysshey shkoly ekonomiki. $832 \mathrm{~s}$. [in Russian].

Polozheniye o domashnikh nastavnikakh $i$ uchitelyakh. [Regulations on home tutors and teachers]. (1875). Sbornik postanovleniy po Ministerstvu narodnogo prosveshcheniya. SPb. T.II. SS. 784 - 798. [in Russian].

Denysenko, M. (2010). Vymohy do orhanizatsii diialnosti huverneriv v Ukraini u pershii polovyni XIX st. [Requirements for the tutors in Ukraine, first half of the $19^{\text {th }}$ century]. Pedahohichni nauky: teoriia, istoriia, innovatsiini tekhnolohii. No 7. SS. 23-29. [in Ukrainian].

Sarapulova, Ye. (2003). Psykholoho-pedahohichni osnovy navchalnovykhovnoi diialnosti huvernera [Psychological and pedagogical basics for the Tutor's educational and pedagogical activities]. Kyiv: MAUP. 264 s. [in Ukrainian].

Drach, O. (2012). Polityka derzhavnoi vlady Rosiiskoi imperii shchodo pedahohichnoi diialnosti inozemtsiv u XIX st. [Russian empire national policy towards foreign pedagogical activities in the $19^{\text {th }}$ century]. Visnyk Cherkaskoho universytetu. Seriia: Istorychni nauky. Vyp. No 29 (242). SS. 15-20. [in Ukrainian].

Obshchiy otchet. predstavlennyy ego imperatorskomu velichestvu po Ministerstvu narodnogo prosveshcheniya za 1836 god [General report for His Imperial Highness of the National Educational Ministry, 1836] (1837). SPb. [in Russian].

Gogolin, A. (1874). Sbornik uzakoneniy $i$ pravitelstvennykh rasporyazheniy. kasayushchikhsya domashnikh nastavnikov. uchiteley. uchitelnits i nastavnits [Legal code for homec tutors and teachers]. M. 38 s. [in Russian].

Prokopenko, L. (2019). Derzhavne rehuliuvannia rozvytku pryvatnoi osvity na Katerynoslavshchyni u pershii polovyni XIX st. [State regulation of the private education on the Katerynoslavshchyna in the first half of the $19^{\text {th }}$ century]. Aspekty publichnoho upravlinnia. T. 7. No 1 -2/ SS. 116-122. 
Інноватика у вихованні. Випуск 13.Том 1. 2021.

\title{
LEGAL REGULATION OF THE UKRAINIAN HOME EDUCATION IN THE SECOND HALF OF THE $19^{\text {th }}$ CENTURY (BASED ON THE "HOME TUTORS AND TEACHERS REGULATION" (1834)
}

\author{
Yulia Petrushko \\ $\mathrm{PhD}$ postgraduate at the Department of Theory and Methods of Education \\ Rivne State University for the Humanities, \\ Rivne, Ukraine \\ ORCID: 0000-0001-7752-5938 \\ e-mail:mosievuch007@ukr.net
}

\begin{abstract}
The article deals with the analysis of the home tutors and teachers' state regulation system in the second half of the $19^{\text {th }}$ century. The main attention is given to legal regulation system analysis, and the "Home Tutors and Teachers Regulation" (1834). The latter officially outlines the "Home Tutor and Teacher regulations", their responsibilities, educational qualifications, financial support and privileges. Based on the research material, archive documents as well as historical and pedagogical studies, the following finding is made: theninstitutionalized legislative regulations of the home educational and pedagogical process officially defined and strengthened home education. The article also states that the second half of the $19^{\text {th }}$ century was a novel phase of the Russian Empire home education development. It lasted till1917 and was defined by clear legislative regulation system for the home teachers and by recognition of the home education as a legal component of the national education system in general.

It is also proved that by the second half of the $19^{\text {th }}$ century legally institutionalized were all necessary conditions granting access to education and children upbringing in the private schools: the existence of the person's special education and moral "reliability", including political views, loyalty to the royal family and Russian Empire national system. The author founded out that foreigners could also be tutors and teachers. However, the unofficial imperial policy towards them was very special and was aimed at minimizing their influence on the home education. Personal and professional requirements for the home teachers were defined in the article. It was also stressed that officially introduced were privileges and benefits granted to home teachers. The cited document legally approved responsibility for breaking the official norms.

Keywords: home education, home tutor, home teacher, legal norms, "Home Tutors and Teachers Regulations".
\end{abstract}

Стаття надійшла до редакиї 28. 04. 2021 р. 